\title{
STRUCTURE AND DIVERSITY OF TREES ON POST-FIRE REGENERATED AREAS IN SIERRA DE GUERRERO, MEXICO
}

\section{ESTRUCTURA Y DIVERSIDAD DE ÁRBOLES EN SITIOS REGENERADOS POST-INCENDIO EN LA SiERRA DE GuERRERO, MÉXICO}

\author{
๑Eduardo Alanis-Rodríguez"1, @laura Sánchez-Castillo¹, @Cuauhtémoc Méndez-Osorio², \\ -Pamela A. Canizales-Velázquez ${ }^{1 *}$, ๑Arturo Mora-Olivo $²$, ${ }^{\circ}$ ernesto A. Rubio-Camacho ${ }^{4}$
}

\author{
${ }^{1}$ Facultad de Ciencias Forestales, Universidad Autónoma de Nuevo León, México. \\ ${ }^{2}$ Escuela Superior en Desarrollo Sustentable, Guerrero, México. \\ ${ }^{3}$ Instituto de Ecología Aplicada, Universidad Autónoma de Tamaulipas, México. \\ ${ }^{4}$ Campo Experimental Centro-Altos de Jalisco, Centro de Investigación Regional Pacífico Centro, INIFAP, Jalisco, México \\ ${ }^{*}$ Corresponding Author: pamela.canizalesvlz@uanl.edu.mx
}

\begin{abstract}
Background: It is known that forest ecosystems have the capacity to regenerate over time. However, the anthropogenic influence over them arises the question on how different the original ecological conditions are after regeneration.

Question: Do fires and agrochemicals have an influence on tree diversity in the study area?

Studied species/ Data description/ Mathematical model: The structure and diversity data obtained from tree communities on four different areas were evaluated. The evaluated areas were a control area (mature forest without management) and three areas with different managements: reforested area, restored area and fumigated area.

Study site and years of study: The study area was located in the Sierra de Guerrero, Mexico on areas affected by a fire that occurred in 2005. Seven years after the fire, in 2012, the investigation was performed.

Methods: In each selected area a census of all tree species was carried out. The density, dominance, frequency, and importance value index were determined per species. Moreover, the diversity at community level and richness were estimated.

Results: The control area showed highest values of density and dominance. The regenerated and reforested area showed highest values of specific richness and diversity.

Conclusions: The evaluated areas showed significant differences when comparing diversity and structure indexes. It is recommended to implement reforestation actions in areas affected by forest fires.

Keywords: density, dominance, mixed forest, Pinus radiata, Quercus glaucescens, species richness.

\section{Resumen}

Antecedentes: Es conocido que los ecosistemas forestales tienen la capacidad de regenerarse con el tiempo. Sin embargo, la influencia antropogénica hace surgir la pregunta de qué tan diferentes son las condiciones ecológicas originales después de la regeneración.

Preguntas: ¿El fuego y los agroquímicos tienen una influencia en la diversidad arbórea en el área de estudio?

Especie en estudio / Descripción de datos / Modelo matemático: Se analizó la información de estructura y diversidad de comunidades arbóreas en cuatro áreas diferentes. Las áreas evaluadas fueron un área de control (bosque maduro sin manejo) y tres áreas con diferentes manejos: un área reforestada, una restaurada y una fumigada.

Sitio de estudio y fechas: El área de estudio se localizó en Sierra de Guerrero, México, en áreas afectadas por un fuego que ocurrió en 2005. La investigación fue realizada siete años después del incendio forestal durante el 2012.

Métodos: Se realizó un censo de todas las especies arbóreas en cada área seleccionada. Por cada especie se determinaron la densidad, frecuencia y el índice de valor de importancia. También se estimó la diversidad y riqueza de especies por cada área.

Resultados: El área de control mostró los valores de densidad y dominancia más altos. El área regenerada y el área reforestada mostraron los valores más altos en riqueza específica y diversidad de especies.

Conclusiones: Las áreas evaluadas presentaron diferencias significativas al comparar los índices de estructura y diversidad. Es recomendable implementar acciones de reforestación en áreas afectadas por incendios.

Palabras clave: bosque mixto, densidad, dominancia, Pinus radiata, Quercus glaucescens, riqueza de especies.
\end{abstract}


The vegetation is organized in biomes and vegetation types that are the result of precipitation and temperature combinations (Walter 1973, Whittaker 1975, Ratnam 2019). However, it is also widely agreed that while those temperature and precipitation combinations define the biomes at major scale, the local state turnover in vegetation types can be driven by differences in topographic and edaphic conditions but most commonly by vegetation disturbances that can result in very different ecosystems within similar climatic conditions (Hoffmann et al. 2012, Charles-Dominique et al. 2015, Pausas \& Dantas 2017, Ratnam 2019).

Among the common causes of vegetation disturbances in Mexico are the forest fires, which are transforming landscapes and ecosystems rapidly due to the increase of man-made fires (Martínez-Hernández \& Rodríguez-Trejo 2008, Rodríguez-Trejo \& Myers 2010). Also, anthropogenic activities on the transformation of forest land to agricultural fields with the use of fire, which is an ancestry activity in Mexico, especially in Sierra Madre del Sur (Beaty \& Taylor 2008, Chávez et al. 2016), where, marijuana and poppy crops have caused significant environmental impacts to the natural ecosystems (Medel et al. 2015), can be assessed through the structure and diversity of the plant communities affected (Alanís-Rodríguez et al. 2008, González-Tagle et al. 2008, Rodríguez-Trejo \& Myers 2010, Jiménez-Pérez \& Alanís-Rodríguez 2011). Until now, there are not studies that explore the effect of fires, landscape conversion and agrochemicals for crop maintenance on the original vegetation conditions (Alanís et al. 2008, González-Tagle et al. 2008, Rodríguez-Trejo \& Myers 2010, Jiménez-Pérez \&
Alanís-Rodríguez 2011, Viana-Soto et al. 2017). Sierra de Guerrero, Mexico, is an ideal place to give answer to our research question: Do fires and agrochemicals have an influence of tree diversity? Therefore, the aim of this study is to evaluate the structure and diversity of post-fire regenerated areas in Sierra de Guerrero, Mexico, contrasting four areas with different conditions: a control area and three regenerated post-fire areas with different treatments (fumigated, reforested and regenerated).

\section{Materials and methods}

Study area. The research was carried out in the Sierra Madre del Sur in the municipality of Chilpancingo, Guerrero (Southern Mexico) (Figure 1). The temperature range between 14 to $28{ }^{\circ} \mathrm{C}$ and rainfall between $800-2,500 \mathrm{~mm}$. The weather is warm and sub-humid with rains in summer. The soil type is luvisol and regosol, while dominant vegetation is forest with agricultural areas (INEGI 2009). The study area shows a high biological richness and the presence of endemic species (Luna-Vega \& LlorenteBousquets 1993). Preliminary field surveys determined the main vegetation type in the area as Pinus-Quercus mixed forest. Also, surveys with local people were used to define the common conditions of post-fire regenerated vegetation communities.

Therefore, four areas with different management conditions were chosen: 1) Reforested 2) Fumigated, 3) Regenerated and 4) Control. Excepting the Control area, the reforested, fumigated and regenerated areas showed postfire plant communities under different management

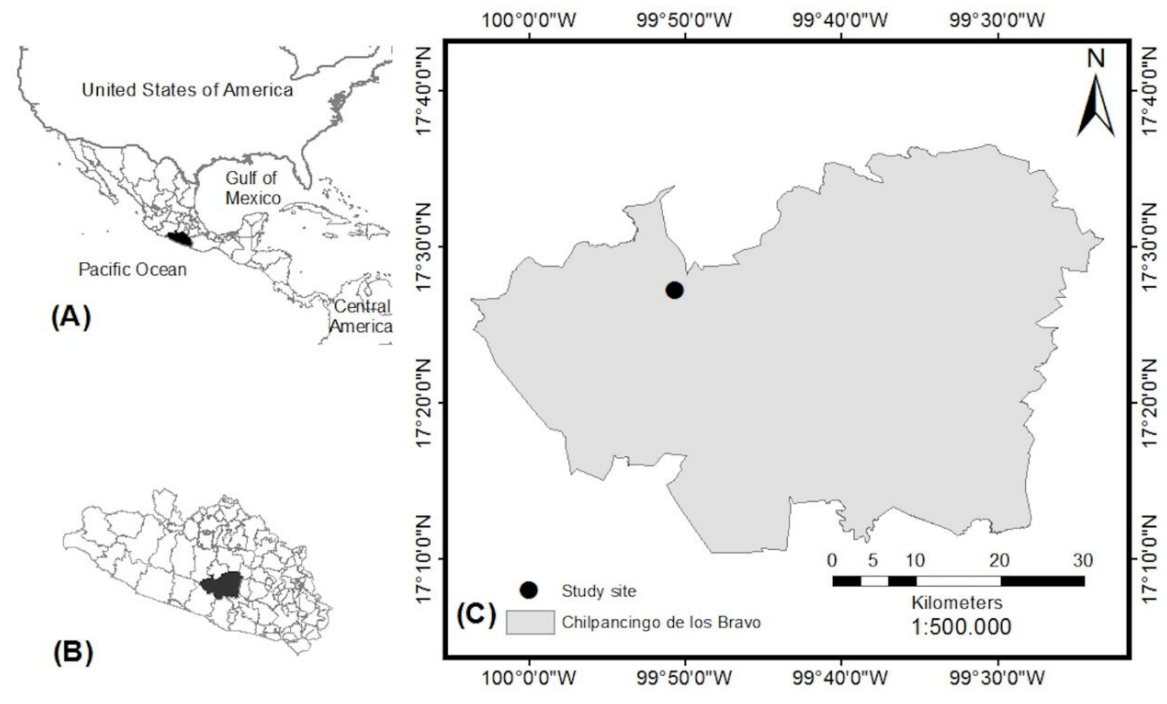

Figure 1. Study area location. A) Mexico, B) Guerrero State, and C) municipality of Chilpancingo. 
conditions. All the areas are similar in physiographic characteristics $(2,100 \mathrm{~m}$ asl slope of $20 \%$, and northeast exposure; Méndez-Osorio et al. 2014).

The forest fires were originated from prescribed burns that went out of control, the fires had an average severity and occurred between April and May (surveys with local people). The reforested area was burned in 2005 but reforested shortly after with Pinus douglasiana, Martínez. The fumigated area was burned in 2004 and fumigated with a broad spectrum non-selective herbicide that acts by contact (Rao 2014). The regenerated area presented unassisted natural succession, after a fire burned it down in 2005. The control area presented a mature forest community conformed by no-native vegetation species because it was intensively reforested during the 60 s and early 70 s with Pinus radiata D. Don (Arteaga-Martínez 2000).

Evaluation of the vegetation. The sampling was performed on September of 2012, during the rainy season. Five circular plots of $1,000 \mathrm{~m}^{2}$ were established for each area, for a total of $20,000 \mathrm{~m}^{2}$. A census of all the tree species was carried out, recording dendrometric measurements of total height (h), normal diameter (DBH) and crown diameter.

Data Analysis. Relative and absolute values of density, dominance (coverage) and frequency and Importance Value Index (IVI) were determined by each species (Curtis \& Mcintosh 1951). Species richness (S) was quantified as the total number of species and the Shannon index and Index of entropy $\left(\mathrm{H}^{\prime}\right)$ was calculated for each area (Magurran 2004). The equations used to determine the diversity indexes and ecological indicators of the species are showed in Table 1.

In order to draw conclusions about the differences in diversity and structural variables between areas, we analyzed the data using two different approaches. When the data satisfied the parametric assumptions, we used the analysis of variance ANOVA and, as Post Hoc, the Tukey HSD test. However, when data did not satisfy these assumptions, we employed the non-parametric KruskalWallis with the Wilcox test as Post Hoc approximation ( $\mathrm{Zar}$ 2010). The statistical analysis where carried out using $R$ ( $\underline{\text { R Core Team 2016). }}$

\section{Results}

There were 14 species, 12 genera and 11 families. Families having two species were: Betulaceae, Pinaceae, Fabaceae and Fagaceae (Table 2). Alnus acuminata and Carpinus caroliniana (both Betulaceae) were only present in the regenerated area, while Acacia farnesiana and
Indigofera palmeri (both Fabaceae) were in the regenerated and fumigated area. Quercus was present in all areas with species such as: Quercus glaucescens and $Q$. uxoris and Pinaceae was represented by Pinus radiata and $P$. douglasiana in the regenerated, reforested and control area.

Absolute and relative density $\left(R_{\text {den }}\right)$. The control area registered the highest relative density values: $720 \pm 15 \mathrm{~N}$ $\mathrm{ha}^{-1}$ (average \pm standard deviation) followed by the reforested area with $626 \pm 4 \mathrm{~N} \mathrm{ha}^{-1}$, which was different from the other sampled areas $(F=130, \mathrm{df}=3, p<0.001)$. The fumigated area showed the lowest relative density (122 $\pm 12 \mathrm{~N} \mathrm{ha}^{-1}$ ) (Figure 2A). The species with the highest relative density per area were reforested, Pinus douglasiana (45.1 \%); regenerated, P. radiata (52.6\%); fumigated, Wigandia urens $(54.1 \%)$ and control: P. radiata $(42.8 \%$; Table 2).

Absolute and relative dominance $\left(R_{\text {dom }}\right)$. The contrast of means allows us to detect differences between sampling areas. Regardless of species, the higher canopy cover per area was observed in the control above all the areas $(F=36.7, \mathrm{df}=3, p<0.001)$; however, other contrasts showed no significant differences. The control area showed a higher canopy coverage of $8,018 \pm 536 \mathrm{~m}^{2} \mathrm{ha}^{-1}$ while the fumigated area showed the lowest $\left(86 \pm 30 \mathrm{~m}^{2} \mathrm{ha}^{-1}\right)$. The canopy coverage value per dominant species were as follows: $P$. douglasiana: $49.5 \%$ in the reforested area; P. radiata: $56.7 \%$ in the regenerated area, $W$. urens: $73.2 \%$ in the fumigated area, while in the control area the dominant P. radiata showed $49.6 \%$ of canopy coverage (Table 2 ).

Species richness $(S)$. In order to make contrasts, the species richness (S) was computed by area, which allows to compute means, medians and standard errors for each area. Significant differences were found through the KruskalWallis test $\left(\chi^{2}=13.4, \mathrm{df}=3, p=0.003\right)$. The fumigated area showed the lowest average specific richness: $4 \pm 1$ species (average number of species \pm standard deviation), however, significant differences were found in the reforested area $(p=0.016)$ with the highest number of species $(6 \pm 1)$ and in the control area $(p<0.008)$, (Figure 2C).

Shannon index $\left(H^{\prime}\right)$. Shannon index values showed the same trend as the species richness, registering significant differences $(F=7.37, \mathrm{df}=3, p=0.002)$. The index of entropy showed significant differences $(F=7.97, \mathrm{df}=3$, $p=0.002$ ) (Figure 3 ). The area with the highest values of $H^{\prime}$ was the reforested with $H^{\prime}=1.46 \pm 0.15$, which corresponds to 4 equally common species $\left(\exp ^{H}\right)$, followed by the regenerated area $\left(H^{\prime}=1.11 \pm 0.29\right)$ which corresponds to 
Table 1. Equations used to determine indexes and ecological indicators for each species.

Equation Where:

Absolute density $\left(\mathrm{A}_{\text {den }}\right)$ and relative density $\left(R_{\text {den }}\right)$

$$
\begin{array}{cl}
A_{\text {den }}=\frac{N_{1}}{S} & A_{\text {den }}=\text { Absolute density } \\
& R_{d e n}=\text { Relative density per species } \\
R_{\text {den }}=\left(\frac{A_{\text {den }}}{\sum_{j=1} A_{d e n}}\right) * 100 \quad & N_{i}=\text { number of individuals of species } \\
& S=\text { sampling area (ha) } \\
& \text { Source: } \text { Curtis \& Mcintosh (1951) }
\end{array}
$$

Absolute dominance $\left(\mathrm{A}_{\mathrm{dom}}\right)$ and relative dominance $\left(R_{\text {dom }}\right)$

$$
\begin{array}{cl}
A_{\text {dom }}=\frac{B_{a}}{S} & A_{\text {dom }}=\text { absolute dominance } \\
R_{\text {dom }}=\left(\frac{A_{d o m}}{\sum_{j=1} A_{d o m}}\right) * 100 & \text { relative dominance of species } \\
& B_{a}=\text { basal area of species } i \\
& S=\text { sampling area (ha) } \\
& \text { Source: } \text { Curtis \& Mcintosh (1951) }
\end{array}
$$

Absolute frequency $\left(\mathrm{A}_{\text {fre }}\right)$ and relative frequency $\left(R_{\text {fre }}\right)$

$$
\begin{gathered}
A_{\text {fre }}=\frac{P_{i}}{N S} \\
R_{\text {fre }}=\left(\frac{A_{\text {fre }}}{\sum_{j=1} A_{\text {fre }}}\right) * 100
\end{gathered}
$$

$A_{\text {fre }}=$ absolute frequency

$R_{\text {fre }}=$ relative frequency of the species i respecting the total frequency

$P_{i}=$ area number in where the species $i$ is present

$N S=$ total number of sampling areas

Source: $\underline{\text { Curtis \& Mcintosh (1951) }}$

Importance value index (IVI)

$$
I V I=\frac{R_{\text {den }}+R_{\text {dom }}+R_{\text {fre }}}{3}
$$

$I V I=$ importance value index

$R_{d e n}=$ relative density per species respecting the total density

$R_{\text {dom }}=$ relative dominance of species i respecting the total dominance

$R_{\text {fre }}=$ relative frequency of the species i respecting the total frequency

Source: Curtis \& Mcintosh (1951)

Shannon index $\left(H^{\prime}\right)$ and index of entropy $\left({ }^{\prime} D\right)$

$$
\begin{array}{cl}
H^{\prime}=\sum_{i=1}^{S} p_{i}{ }^{*} \ln \left(p_{i}\right) & H^{\prime}=\text { Shannon index } \\
p_{i}=n_{i} / N & S=\text { number of species } \\
1 D=\exp \left(H^{\prime}\right) & N=\text { total number of individuals } \\
& n_{i}=\text { number of individuals of species i } \\
& { }^{I} D=\text { Index of entropy } \\
& \text { exp }=\text { exponential } \\
& \text { Source: Magurran (2004) \& Jost }(2006)
\end{array}
$$


Table 2. Ecological relative parameters of density, dominance, frequency and Importance Index Value of the species founded in the study area.

\begin{tabular}{|c|c|c|c|c|c|c|c|c|c|c|c|c|c|c|c|c|c|}
\hline \multirow[t]{2}{*}{ Family } & \multirow[t]{2}{*}{ Scientific name } & \multicolumn{3}{|c|}{ Fumigated } & area & \multicolumn{4}{|c|}{ Regenerated area } & \multicolumn{3}{|c|}{ Reforested } & area & \multicolumn{4}{|c|}{ Control area } \\
\hline & & $\boldsymbol{R}_{\text {den }}$ & $\boldsymbol{R}_{\text {dom }}$ & $R f_{r}$ & IVI & $\boldsymbol{R}_{d e n}$ & $\boldsymbol{R}_{\text {dom }}$ & $R f_{r}$ & IVI & $\boldsymbol{R}_{\text {den }}$ & $\boldsymbol{R}_{\text {dom }}$ & $R f_{r}$ & IVI & $\boldsymbol{R}_{d e n}$ & $\boldsymbol{R}_{\text {dom }}$ & $R f_{r}$ & $I V I$ \\
\hline Betulaceae & $\begin{array}{l}\text { Alnus acuminata subsp. arguta (Schltdl.) } \\
\text { Furlow }\end{array}$ & & & & & 6 & 2 & 15 & 8 & & & & & & & & \\
\hline Betulaceae & Carpinus caroliniana & & & & & 6 & 2 & 15 & 8 & & & & & & & & \\
\hline Clethraceae & Clethra mexicana DC. & 7 & 7 & 8 & 7 & & & & & & & & & & & & \\
\hline Dilleniaceae & Curatella americana $\mathrm{L}$. & & & & & & & & & 4 & 7 & 15 & 8 & & & & \\
\hline Ericaceae & Arbutus xalapensis Kunth & & & & & & & & & & & & & 41 & 2 & 29 & 24 \\
\hline Fabaceae & Indigofera palmeri $\mathrm{S}$. Watson & 24 & 9 & 31 & 21 & & & & & & & & & & & & \\
\hline Fabaceae & Acacia farnesiana (L.) Willd. & & & & & 9 & 9 & 20 & 13 & & & & & & & & \\
\hline Fagaceae & Quercus glaucescens Bonpl. & 15 & 11 & 23 & 17 & 26 & 30 & 25 & 26 & & & & & 12 & 44 & 29 & 28 \\
\hline Fagaceae & Quercus uxoris McVaugh & & & & & & & & & 8 & 3 & 17 & 10 & 5 & 4 & 13 & 7 \\
\hline Hydrophyllaceae & Wigandia urens (Ruiz \& Pav.) Kunth & 54 & 73 & 38 & 55 & & & & & & & & & & & & \\
\hline Malphigiaceae & Byrsonima crassifolia (L.) Kunth & & & & & & & & & 18 & 6 & 17 & 13 & & & & \\
\hline Melastomataceae & $\begin{array}{l}\text { Conostegia xalapensis (Bonpl.) D. Don ex } \\
\text { DC. }\end{array}$ & & & & & & & & & 15 & 3 & 17 & 12 & & & & \\
\hline Pinaceae & *Pinus radiata D. Don & & & & & 53 & 57 & 25 & 45 & 11 & 31 & 17 & 20 & 42 & 50 & 29 & 41 \\
\hline Pinaceae & *Pinus douglasiana Martínez & & & & & & & & & 44 & 50 & 17 & 37 & & & & \\
\hline & $\sum$ & $=100$ & 100 & 100 & 100 & 100 & 100 & 100 & 100 & 100 & 100 & 100 & 100 & 100 & 100 & 100 & 100 \\
\hline
\end{tabular}

$\mathrm{R}_{\mathrm{den}}=$ Relative density, $R_{\text {dom }}=$ Relative dominance, Relative frequency $=R_{\text {fre }}, \mathrm{IVI}=$ Importance value index, $*=$ introduced species.

3 equally common species $\left(\exp ^{H}\right)$, and the control area $\left(H^{\prime}=1.06 \pm 0.18\right)$, which corresponds to 3 equally common species $\left(\exp ^{H}\right)$. The fumigated area had the lowest value of diversity with $H^{\prime}=0.70 \pm 0.34$ (Figure 2D), which corresponds to 2 equally common species $\left(\exp ^{H}\right)$.

Relative frequency $\left(R_{\text {frr }}\right)$. In the reforested area, the species with highest relative frequency were: $P$. radiata, P. douglasiana, Q. uxoris, Byrsonima crassifolia Kunth and Conostegia xalapensis D. Don with $17 \%$ each. In the regenerated area: Pinus. radiata and Quercus glancescens Bonpl, both species represented $25 \%$ and in the fumigated area $W$. urens represented $38.5 \%$. In the control area the highest relative frequency was represented by three species, Q. glaucescens, P. radiata and Arbutus xalapensis Kunth $29.4 \%$ (Table 2).

Importance Value Index (IVI). Pinus radiata and Q. glaucescens were the species with highest IVI (Table 2), these species were recorded in three of the four analyzed areas. Pinus radiata presented the highest IVI values in the regenerated (45\%) and control areas (41\%), and the second in the reforested area $(20 \%)$. Quercus glaucescens was the second species with the highest IVI in the regenerated
(26\%) and control areas (28\%), and the third species with the highest importance value index in the fumigated area $(17 \%)$. In the reforested area, the species with the highest importance value index was $P$. douglasiana (37\%) (Table 2).

\section{Discussion}

Alnus acuminata and Carpinus caroliniana belonging to Betulaceae were found only in the regenerated area. Those species are usually present in secondary successional stages of Pine forest and Pine-Oak forests, this can be explained as a direct consequence of the forest destruction and habitat fragmentation (CONAFOR 2020, Luna-Vega 2003). Acacia farnesiana that was also in the regenerated area is often occurring in disturbed areas as an important element of secondary vegetation (CONABIO 2020). The Fagaceae and Pinaceae families were the most representative in this study, which is similar to previous studies conducted in mixed forests under different conditions in Mexico (Alanís et al. 2012, Almazán-Núñez et al. 2016, Graciano-Ávila et al. 2017).

The statistical difference between the relative density in 
A

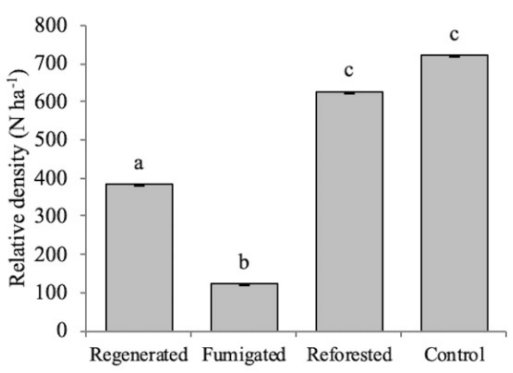

C

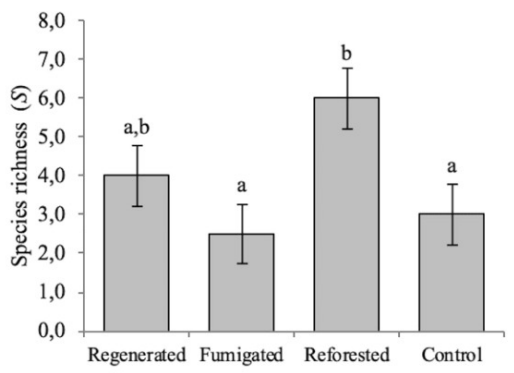

B

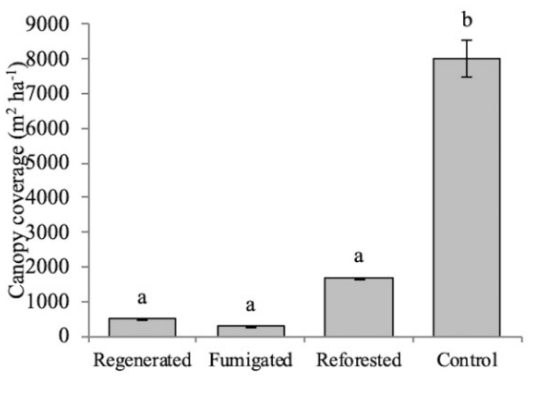

D

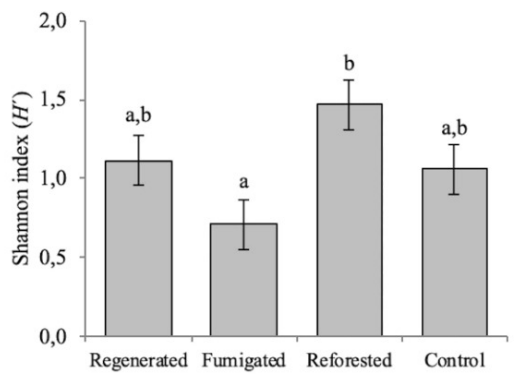

Figure 2. A) Relative density $\left(\mathrm{N}^{-1}\right)$, B) canopy coverage $\left(\mathrm{m}^{2} \mathrm{ha}^{-1}\right)$, C) Species richness $(\mathrm{S})$, and $\left.\mathrm{D}\right)$ Shannon index $\left(\mathrm{H}^{\prime}\right)$. Average and standard deviation values for each evaluated area was showed. Different letters indicate significant differences (Tukey, $p<0.05$ ).

the regenerated and fumigated areas could indicate that the fumigation process affected the development of individuals in the area after the fire. No differences were detected for the reforested and control areas, which is similar to what was found by Almazán-Núñez et al. (2016), who evaluated a secondary mixed Pine-Oak forest in the Sierra Madre del Sur at different successional stages. Relative density in post-fire environment species adaptation plays an important role, such is the case of Pinus douglasiana that showed the highest number of individuals (which is expected because $P$. douglasiana was used for reforestation of the area). This species has the capacity to grow with success in post-fire environments because it requires abundant light when growing (CONAFOR 2018a).

The forest fires promote the dehiscence of the cones of $P$. radiata individuals, allowing the dispersal of seeds (Vallejo et al. 2012). Also, some factors that could be influencing individuals of $P$. radiata include orientation (northeast) and slope conditions (CONAFOR 2018b) variables that could be included in further studies. Regarding the adaptation of individuals to the fumigated area we observed that $W$. urens could be important to agrochemical treatments since it was a species with high density despite being in a highly disturbed area (Nash 1979, Vibrans 2009). The effect of the forest fire on the canopy coverage is significant since all the areas were compared to the control area, which showed the highest canopy coverage. Previous studies such as Almazán-Núñez et al.
(2016), reported the highest canopy coverage on a mature mixed forest.

The results regarding richness and diversity of species of this study were similar to some previous studies where it was found that fire do not affect trees diversity and on the contrary enhance species number in some cases, being considered as a significant evolutionary force (Keeley et al. 2011, Gallegos-Rodríguez et al. 2014, Hedo et al. 2015, Pereira et al. 2016, Foster et al. 2017). The diversity of the fumigated area was similar to the control area but lower to the other areas. The influence of fire and fumigation was negative for plant community restoration, resulting on a lower value of richness and diversity of species for the fumigated area (Figure 2). The frequency was different in species, where $W$. urens was the most frequent. RubioCamacho et al. (2016) found this species in an area with evidence of fire but without concluding any relation. This opens the opportunity to further research regarding post-fire and species adaptation.

The importance value index of species of $Q$. glaucescens was second highest in this study for all areas; however, it was reported by Alanís-Rodríguez et al. (2012) and RubioCamacho et al. (2016) as the highest on post-fire studies; proving that Quercus species have a high cope capacity to fire. The species of Quercus have an evolutionary strategy to re-sprout; thus, individuals of this species are present in the burned area (Pausas 2004, Encina-Domínguez et al. 2009, Alanís-Rodríguez et al. 2012). 


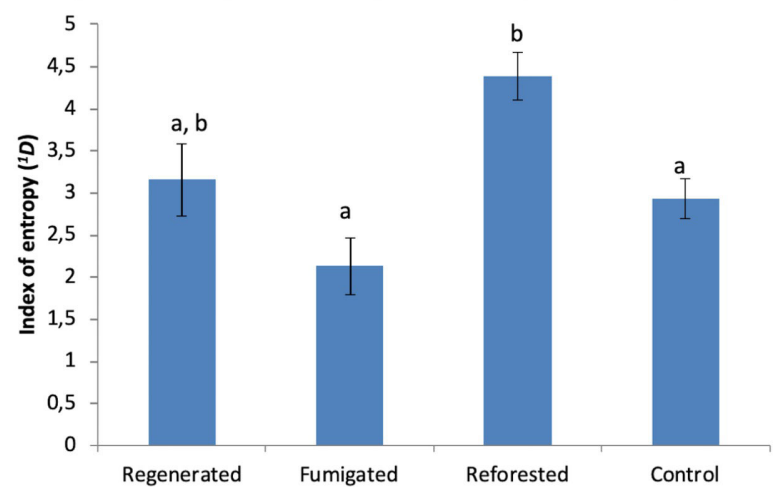

Figure 3. Index of entropy in the four areas post-fire regenerated in the Sierra de Guerrero, México. Different letters indicate significant differences (Tukey, $p<0.05$ ).

As general conclusions, we found that the highest IVI on Pinus and Quercus genera, which indicated fire resilience on $P$. radiata, $P$. douglasiana, $Q$. glaucescens and $Q$. uxoris species. However, the area where the agrochemicals were used showed the lowest values of abundance, dominance, species richness and measured indexes. This suggests that fire associated with fumigation activities on plant communities affects significantly the structure and diversity of entire areas. Further studies on post-fire areas under different treatments are encouraged to increase the knowledge of the restoration of plant communities.

\section{Acknowledgments}

We thank all the people who supported the field activities.

\section{Literature cited}

Alanís-Rodríguez E, Jiménez-Pérez J, Espinoza-Vizcarra D, Jurado-Ybarra E, Aguirre-Calderón OA, González-Tagle MA. 2008. Evaluación del estrato arbóreo en un área restaurada post-incendio en el Parque Ecológico Chipinque. Revista Chapingo Serie Forestales y del Ambiente 14: 113-118.

Alanís-Rodríguez E, Jiménez-Pérez J, Valdecantos-Dema A, González-Tagle MA, Aguirre-Calderón OA, TreviñoGarza EJ. 2012. Composición y diversidad de la regeneración natural en comunidades de Pinus-Quercus sometidas a una alta recurrencia de incendios en el noreste de México. Revista Mexicana de Biodiversidad 83: 1208-1214. DOI: http://dx.doi.org/10.22201/ib.2007 $\underline{8706 e .2012 .4 .1013}$

Almazán-Núñez RC, Corcuera P, Parra-Juárez L, JiménezHernández J, Michäel-Charre G. 2016. Changes in structure and diversity of woody plants in a secondary mixed pine-oak forest in the Sierra Madre del Sur of
Mexico. Forests 90: 1-15. DOI: https://doi.org/10.3390/ $\underline{\mathrm{f} 7040090}$

Arteaga-Martínez B. 2000. Evaluación dasométrica de plantaciones de cuatro especies de pinos en Ayotoxtla, Guerrero. Revista Chapingo: Serie Ciencias Forestales y del Ambiente 6: 151-157

Beaty RM, Taylor AH. 2008. Fire history and the structure and dynamics of a mixed conifer forest landscape in the northern Sierra Nevada, Lake Tahoe Basin, California, USA. Forest Ecology and Management 255: 707-719. DOI: https://doi.org/10.1016/j.foreco.2007.09.044

Charles-Dominique T, Staver AC, Midgley GF, Bond WJ. 2015. Functional differentiation of biomes in an African savanna/forest mosaic. South African Journal of Botany 101: 82-90. DOI: https://doi.org/10.1016/j.sajb.2015.05. $\underline{005}$

Chávez AJ, Xelzuantzi J, Rubio EA, Villanueva J, Flores H, Mora C. 2016. Caracterización de cargas de combustibles forestales para el manejo de reservorio de carbono y la contribución al cambio climático. Revista Mexicana de Ciencias Agrícolas 13: 2589-2600.

CONABIO [Comisión Nacional para el Conocimiento y Uso de la Biodiversidad]. 2020. Acacia farnesiana. http://www.conabio.gob.mx/conocimiento/info_especies/ arboles/doctos/38-legum4m.pdf (accessed February 28, 2020)

CONAFOR [Comisión Nacional Forestal]. 2018a. Pinus douglasiana Martínez. SIRE Paquetes Tecnológicos. http://www.conafor.gob.mx:8080/documentos/docs/13/9 58Pinus\%20douglasiana.pdf (accessed August 23, 2018).

CONAFOR [Comisión Nacional Forestal]. 2018b. Pinus radiata D. Don. SIRE Paquetes Tecnológicos. http:// www.conafor.gob.mx:8080/documentos/docs/13/982Pin us\%20radiata.pdf (accessed August 23, 2018).

CONAFOR [Comisión Nacional Forestal]. 2020. Alnus acuminata H.B.K. SIRE Paquetes Tecnológicos. $<\underline{\text { http: } / /}$ www.conafor.gob.mx:8080/documentos/docs/13/882Aln us\%20acuminata.pdf $>$ (accessed February 28, 2020)

Curtis JT, McIntosh RP. 1951. An upland forest continuum in the pariré-forest border region of Wisconsin. Ecology 32: 476-496.

Encina-Domíguez JA, Zárate-Lupercio A, Estrada-Castillón E, Valdés-Reyna J, Villarreal-Quintanilla JA. 2009. Composición y aspectos estructurales de los bosques de Encino de la Sierra de Zapalinamé, Coahuila, México. Acta Botánica Mexicana 86: 71-108. DOI: https:// doi.org/10.21829/abm86.2009.1078

Foster CN, Barton PS, MacGregor CI, Catford JA, Blanchard W, Lindenmayer DB. 2017. Effects of fire regime on plant species richness and composition differ among forest, woodland and heath vegetation. Applied Vegetation Science 21:132-143. DOI: https://doi.org/ $\underline{10.1111 / \text { avsc. } 12345}$ 
Gallegos-Rodríguez A, González-Cueva GA, CabreraOrozco RG, Marcelli-Sánchez C, Hernández-Álvarez E. 2014. Efecto de la recurrencia de incendios forestales en la diversidad arbórea. Revista Mexicana de Ciencias Forestales 24: 110-125.

González-Tagle MA, Schwendenmann L, Jiménez-Pérez J, Schulz R. 2008. Forest structure and woody plant species composition along a fire chronosequence in mixed pineoak forest in the Sierra Madre Oriental, Northeast Mexico. Forest Ecology and Management 256: 161-167. DOI: https://doi.org/10.1016/j.foreco.2008.04.021

Graciano-Ávila G, Aguirre-Calderón OA, Alanís-Rodríguez E, Luján-Soto JE. 2017. Composición, estructura y diversidad de especies arbóreas en un bosque templado del Noroeste de México. Ecosistemas y Recursos Agropecuarios 12: 535-542. DOI: https://doi.org/10.191 36/era.a4n12.1114

Hedo J, Lucas-Borja ME, Wic C, Andres-Abellán M, Heras JDL. 2015. Soil microbiological properties and enzymatic activities of long-term post-fire recovery in dry semiarid Aleppo pine. Solid Earth 6: 243-252. DOI: https://doi.org/10.5194/se-6-243-2015

Hoffmann WA, Geiger EL, Gotsch SG, Rossatto DR, Silva LC, Lau OL, Haridasan M, Franco AC. 2012. Ecological thresholds at the savanna-forest boundary: how plant traits, resources and fire govern the distribution of tropical biomes. Ecology Letters. 15: 759-768. DOI: https://doi.org/10.1111/j.1461-0248.2012.01789.x

INEGI [Instituto Nacional de Estadística y Geografía]. 2009. Prontuario de información geográfica municipal de los Estados Unidos Mexicanos Chilpancingo de los Bravo, Guerrero. Clave geoestadística 12029. P. 99 http://www3.inegi.org.mx/contenidos/app/mexicocifras/ datos geograficos/12/12029.pdf (accessed May 31, 2019).

Jiménez-Pérez J, Alanís-Rodríguez E. 2011. Análisis de la frecuencia de los incendios forestales en la Sierra Madre Oriental y Occidental del norte de México y sur de Estados Unidos de América. Ciencia UANL 14: 255-263.

Jost L. 2006. Entropy and diversity. Oikos 113, 110-116. DOI: https://doi.org/10.1111/j.2006.0030-1299.14714.x

Keeley JE, Pausas JG, Rundel PW, Bond WJ, Bradstock RA. 2011. Fire as an evolutionary pressure shaping plant traits. Trends in Plant Science 16: 406-411. DOI: https:// doi.org/10.1016/j.tplants.2011.04.002

Luna-Vega I, Llorente-Bousquets J. 1993. Historia Natural del Parque Ecológico Estatal Omiltemi, Chilpancingo, Guerrero, México. Ciudad de México: Comisión Nacional para el Conocimiento y Uso de la Biodiversidad (CONABIO)- Universidad Nacional Autónoma de México (UNAM). ISBN: 968-36-3363-3

Luna-Vega MI. 2003. Carpinus caroliniana. Taxones del bosque mesófilo de montaña de la Sierra Madre Oriental incluidos en la norma oficial mexicana. México, DF.: Universidad Nacional Autónoma de México. Herbario FCME, Bases de datos SNIB-CONABIO. http:// www.conabio.gob.mx/conocimiento/ise/fichasnom/Carpi nuscaroliniana00.pdf (accessed February 28, 2020)

Magurran AE. 2004. Measuring biological diversity. Oxford, RU: Blackwell Publishing. ISBN-13: 978-0-632-05633-0

Martínez-Hernández HC, Rodríguez-Trejo DA. 2008. Species diversity after prescribed burns at different intensities and seasons in a high-altitude Pinus hartwegii forest. Interciencia 33: 337-344.

Medel M, Lu Y, Chow E. 2015. Mexico's drug networks: Modeling the smuggling routes towards the United States. Applied Geography 60: 240-247. DOI: https:// doi.org/10.1016/j.apgeog.2014.10.018

Méndez-Osorio C, Alanís-Rodríguez E, Jiménez-Pérez J, Aguirre-Calderón OA, Treviño-Garza EJ. 2014. Análisis de la regeneración post-incendio en un bosque de pinoencino de la Sierra de Guerrero, México. Ciencia UANL 17: 63-70.

Nash DL. 1979. Hydrophyllaceae. Flora de Veracruz. 5: 2-37

Pausas JG. 2004. La recurrencia de incendios en el monte mediterráneo. In: Vallejo VR, Alloza JA, eds. Avances en el estudio de la gestión del monte mediterráneo. pp. 47-64. España: Fundación CEAM, ISBN: 8492125934, 9788492125937

Pausas JG, Dantas VDL. 2017. Scale matters: firevegetation feedbacks are needed to explain tropical tree cover at the local scale. Global Ecology and Biogeography. 26: 395-399. DOI: https://doi.org/10.11 $\underline{11 / \text { geb. } 12562}$

Pereira P, Cerda A, Jordan-Lopez A, Zavala LM, MataixSolera J, Arcenegui V, Misiune I, Keesstra S, Novara A. 2016. Short-term vegetation recovery after a grassland fire in Lithuania: The effects of fire severity, slope position and aspect. Land degradation development 27: 1523-1534. DOI: https://doi.org/10.1002/ldr.2498

R Core Team. 2016. R: A language and environment for statistical computing. $\mathrm{R}$ Foundation for Statistical Computing, Vienna, Austria. https://www.R-project.org/

Rao VS. 2014. Transgenic Herbicide Resistance in Plants. Boca Raton, Florida: CRC Press. ISBN: 9781466587373

Ratnam J, Chengappa SK, Machado SJ, Nataraj N, Osuri AM, Sankaran M. 2019. Functional Traits of Trees from Dry Deciduous "Forests" of Southern India Suggest Seasonal Drought and Fire Are Important Drivers. Frontiers in Ecology and Evolution 7: 8. DOI: https:// doi.org/10.3389/fevo.2019.00008

Rodríguez-Trejo DA, Myers R. 2010. Using oak characteristics to guide fire regime restoration in Mexican pine-oak and oak forests. Ecological 
Restoration 28: 304-323. DOI: https://doi.org/10.3368/ er.28.3.304

Rubio-Camacho EA, González-Tagle MA, BenavidesSolorio JDD, Chávez-Durán AA, Xelhuantzi-Carmona J. 2016. Relación entre necromasa, composición de especies leñosas y posibles implicaciones del cambio climático en bosques templados. Revista Mexicana de Ciencias Agrícolas 13: 2601-2614. DOI: https://doi.org/ $\underline{10.29312 / \text { remexca.v0i13.486 }}$

Vallejo VR, Arianoutsou M, Moreira F. 2012. Fire ecology and post-fire restoration approaches in southern European forest types. In: Moreira F, Arianoutsou M, Corona P, De las Heras J. eds, Post-Fire Management and Restoration of Southern European Forests. Managing Forest Ecosystems 24. pp. 93-119. Dordrecht: Springer. DOI: https://doi.org/10.1007/978-94-007-2208$\underline{8} 5$

\footnotetext{
Associate editor: Enrique Jurado

Author Contributions: EAR: conceived the investigation, methodology design, and data analysis. LSC: conceived the investigation, paper writing, data analysis, revision, and edition of manuscript. CMO: conceived the investigation, field work, data base compilation, and analysis. PACV: conceived the investigation, data analysis, manuscript revision, and editing. AMO: species identification, writing, and revision of manuscript. EARC: data base analysis, revision, and edition of manuscript.
}

Viana-Soto A, Aguado I, Martínez S. 2017. Assessment of post-fire vegetation recovery using fire severity and geographical data in the mediterranean region (Spain). Environments 4: 90. DOI: https://doi.org/10.3390/envi ronments 4040090

Vibrans H. ed. 2009. Malezas de México. Wigandia urens. http://www.conabio.gob.mx/malezasdemexico/hydrophy llaceae/wigandia-urens/fichas/ficha.htm (accessed August 23, 2018).

Walter H. 1973. Vegetation of the Earth in Relation to Climate and the Eco-Physiological Conditions. London: The English Universities Press Ltd. ISBN: 0340171650; 9780340171653

Whittaker RH. 1975. Community and Ecosystems. New York: McMillan.

Zar J. 2010. Biostatistical Analysis. New Jersey, USA: Macmillan. ISBN: 0024273902; 978002427390 